Gelanggang Pendidikan Jasmani Indonesia

\title{
PENGEMBANGAN BAHAN AJAR RENANG GAYA DADA UNTUK MEMPERMUDAH MELATIH RENANG GAYA DADA
}

\author{
Yoga Siddhi Vidyasthana Saputra ${ }^{\square}$, Rufi' $^{\prime} \mathbf{i}^{2}$, Abd. $^{\text {Cholid }}{ }^{3}$ \\ 1,2, ${ }^{3}$ Universitas PGRI Adi Buana Surabaya \\ yogasiddhivs@gmail.com
}

Info Artikel

Sejarah Artikel:

Diterima: April-2020

Disetujui: Mei-2020

Dipublikasikan : Juni-2020

Kata Kunci:

bahan ajar, metode renang, gaya dada

\section{Abstrak}

Penelitian bertujuan untuk mengembangkan modul pelatihan renang gaya dada untuk mempermudah para pelatih renang gaya dada dalam aktivitas sebagai pelatih. Metode Penelitian dan Pengembangan digunakan untuk menghasilkan produk pengembangan berupa pelatihan renang gaya dada. Teknik pengumpulan data menggunakan angket tentang respons para pelatih dan siswa yang dianalisis menggunakan statistik deskriptif yang penyajianya dalam bentuk persentase. Hasil penelitian ini menunjukkan bahwa, uji validasi produk oleh ahli desain pembelajaran, ahli materi renang, pada uji coba lapangan mulai dari teman sejawat dan siswa renang, uji coba pelatih kelompok kecil dan siswa pelatih kelompok kecil, uji coba lapangan pelatih kelompok besar dan siswa pelatihan kelompok besar masuk pada kategori sangat baik. Dengan demikian modul pengembangan pembelajaran renang dengan yoga methods layak digunakan oleh para pelatih renang gaya dada.

\section{Abstract}

This study aims to develop a breaststroke swimming training module to facilitate breaststroke swimming trainers in their activities as trainers. Research and Development methods are used to produce development products in the form of breaststroke swimming training. The data collection technique used a questionnaire about the responses of the trainers and students who were analyzed using descriptive statistics which were presented in the form of a percentage. The results of this study indicate that, product validation tests by instructional design experts, swimming material experts, in field trials ranging from peers and swimming students, small group trainer trials and small group trainer students, large group trainer field trials and student training large groups fall into the very good category. Thus the module of developing swimming learning with yoga methods is suitable for use by breaststroke swimming trainers.

(C) 2020 Universitas Negeri Malang 


\section{PENDAHULUAN}

Beberapa peneitian tentang pelatihan gaya renang telah dilakukan, Di antaranya adalah penelitian pembelajaran gaya crawl dengan metode multi-stroke dan flipper float (Subagiyo dan Sismadiyanto, 2001), pengaruh gaya berenang terhadap volume oksigen (Dennison, Sriwahjuni, and Wardhani, 2003), pendekatan kontekstual pada renang gaya dada (Ali, 2012), dan pengaruh frekuensi gerakan nkaki terhadap prestasi renang gaya crawl (Prasetyo dan Yusuf, 2017).

dunia ini manusia terus beradaptasi sesuai perkembangan zaman, maka dari itu di dunia ini terus belajar dan belajar sangat penting bagi kehidupan manusia, dengan belajar maka manusia akan selalu dapat mengikuti alur dan tidak ketinggalan zaman dan selalu dapat mengembangkan dirinya sesuai dengan keadaan yang sebenarnya, suka tidak suka manusia akan menyesuaikan lingkunganya dengan rasa ikhlas maupun dengan sangat terpaksa, memang itulah realita kehidupan yang harus dijalani sekarang dan seterusnya, perkembangan teknologi sangat mempengaruhi prilaku manusia yang dulu konvensional yang kini lebih serba digital (Ngafifi, 2014). Hal ini berlaku juga pada dunia renang. Dunia renang perkembang seriring perkembangan jaman yang akan berguna untuk kehidupan yang berkelanjutan dan kemudian yang berdampak untuk kemajuan bangsa dan negara Indonesia. Renang memberikan manfaat, yakni meningkatkan kemampuan otak, mengurangi stress, dan menaikkan daya tahan tubuh (Susanto, 2010).

Oleh karena itu pembelajaran renang, yang merupakan bagian dari pendidikan jasmani, adalah salah satu pembelajaran yang dikembangkan di sekolah-sekolah. Di sekolah Indonesia terdapat fasilitas pendidikan formal dan non-formal dan Pemerintah menggalakkan belajar 12 tahun, jadi dengan seperti itu semua warganya mempunyai kesempatan yang sama dalam mendapatkan ilmu pengetahuan di negara yang kita cintai ini, dengan menempuh pendidikan pastilah semua siswa akan mengalami pengalaman yang berbeda-beda, mulai dari kemudahan, kesulitan dalam belajar, dan semua itu akan dialami berulang-ulang disetiap jenjang dan tingkat di sekolah, kemudahan dan kesulitan belajar karena dipengaruhi banyak faktor kurangnya kreatifitas seorang gurunyang membuat murid dapat menjadi tertarik ke suatu bidang yang dinajarkan contohnya kurangnya pengajar dalam media peraga dan sebagainya. Atau dari faktor internal siswa sendiri, mungkin kurangnya motivasi diri, sikap, minat, kebiasaan belajarnya kurang, kurangnya konsep diri yang pada siswa atau kemampuan diri yang kurang sejak lahir. Jadi initinya kesulitan belajar siswa dapat dipengaruhi dari dia faktor yaitu eksternal dan internal siswa.

Kesulitan-kesulitan belajar tidak dirasakan siswa-siswi disekolah aja melainkan diberbagai hal di aktivitas yang baru dilakukan, dan semua manusia pasti akan menyesuaikanya. Dengan demikian apa yang akan dicapai sedikit demi sedikit akan tercapai.

Pendidikan jasmani olahraga dan kesehatan yang diajarkan disekolah mulai aktivitas di darat, aktivitas di air dan kesehatan, contoh aktivitas di darat seperti permainan bola besar dan kecil, beladiri, permainan tradisional, sedangkan aktivitas air seperti renang, penyelelamatan di air, dari unsur kesehatan seperti penyakit menular tidak menular, narkoba lain-lainya, dan dalam penelitian pengembangan ini peneliti mengembangkan pembelajaran renang dan lebih spesifik lagi yaitu pengembangan pelatihan renang gaya dada.

Dalam pembelajaran apapun pasti ada proses seperti contoh-nya orang tidak pernah sepak bola disuruh sepak bola, pasti dalam praktiknya akan membuat orang yang melihat menjadi lucu karena ketidak mampuan bermain sepak bola, ataupun sebaliknya orang yang tidak mampu bermain sepakbola malah tidak mau bermain sepak bola. Demukian juga pada olahraga air, seperti orang tidak mampu berenang ada yang merasa tertantang mau belajar ranang dan ada juga malah tidak berani berenang, biasanya orang yang tidak mampu dengan hal yang baru akan merasa cemas dan cenderung takut menjalani hal baru tersebut.

Seorang pembina atau pelatih ataupun guru renang pasti mempunyai berbagi tips untuk membuat semua orang yang mau belajar renang menjadi senang dan berbagi jurus apapun akan dilakukan, apalagi profesi hidupnya hanya sebagai pelatih renang, pastinya segala daya upaya akan dilakukan supaya calon siswa dan siswa merasa nayaman dalam belajar dan hilang rasa takut, cemas yang akhirnya dapat menimbulkan motivasi diri siswa san rasa percaya diri-nya meningkat yang pada akhirnya pembelajaran itu menjadi kebutuhan bagi para siswa, dengan pembelajaran yang seperti itu maka pembelajaran dapat membuat siswa menjadi senang dan pada akhirnya pelatihan renang pun berjalan dengan baik dan komprehensif.

Ada beberapa buku renang yang ada di sekolah seperti buku penjas mulai buku penjas SD, SMP, SMA/SMK yang ada materi renang tetapi di isi materi menerangkan tata cara melatih renang dengan hanya beberapa anggota tubuh dan dianggap oleh peneliti tidak mempunyai urutan yang baku 
maka dari itu peneliti dengan beberapa pengalaman menjadi pelatih renang tentunya harus membakukan suatu urutan metode pelatihan tersebut, metode-metode yang digunakan peneliti dengan pengalaman saat ini sangat banyak dan bervariasi demi mensuksekkan pelatihan renang tersebut dan setiap orang berbeda latar belakang jadi beda treatment yang dilakukan yang dilakukan, dalam menjalani sebagai seorang Personal trainer (PT) renang hal yang perlu dihindari ialah berpikir secara negatif, seperti bebrbut hal yang menguntungkan diri dan merugikan murid, sebagai contoh jangan pernah seorang pelatih mempunyai pandangan " kalau bisa diperlama pembelajaran kenapa harus di percepat" pandangan seperti ini menurut peneliti sangat tidak layak di miliki oleh seorang pelatih renang karena sifatnya pelatihan dibuat-buat lebih lama supaya siswa mengeluarkan biaya renang menjadi lebih banyak diluar kewajaran sesuai kemampuan siswa tersebut.

Supaya pemikiran negatif tidak timbul maka peneliti mencoba memberikan salah satu laternatif dan berbagi tips treatment khusus cara melatih renang gaya dada dengan praktis, dengan harapan dan tujuan yang baik dan tanpa mengurangi rasa nikmat dan syukur kita kepada Tuhan Yang maha Kuasa, bahwa rezeki kita akan datang apabila kita mau berusaha, dengan pemikiran itu maka peneliti dalam melaksanakan pelatihan renang gaya dada tidak pernah berfikir negatif yang berdampak merugikan para siswa. Pandangan peneliti dalam melatih ialah: kalau di buat cepat dapat kenapa diperlama, dengan dasar pemikiran itu peneliti selalu berupaya terus menerus untuk berpikir dengan berbagai metode apa saja yang dapat membuat siswa renang secara cepat menguasai materi renang gaya dada dalam praktiknya. Walaupun setiap siswa dengan kemampuanya berbeda setidaknya pelatih selalu memberi pelatihan yang maksimal, dan pelatih menawarkan salah satu tips secara praktis dan nyaman untuk pelatihan bagi peserta atau siswa renang gaya dada.

Setiap pelatih pada umunya mempunyai metode-metode yang berbeda-beda tapi tujuan utamanya sama yaitu membuat siswa yang belum mampu berenang menjadi mampu dan menguasai gaya renang yang di ajarkan atau dilatihkan dengan baik, supaya renang menjadi salah satu kebutuhan setiap orang guna menjaga kesehatanya dan setidaknya menjadikan hoby baru bagi mereka yang pernah berlatih renang.

Jika pelatih renang dapat membuat siswa renang dari takut menjadi kecanduan renang atau menjadi kebutuhan pasti semua orang akan menilai pelatih renang tersebut berhasil dan sukses dalam menjalankan amanah yang diberikan oleh siswa ataupun wali siswa renang, dan tentunya juga akan menapatkan promosi gratis dari para siswa dan wali siswa dengan pemberitaan melalui mulut ke mulut dan sebagainya, maka dengan sendirinya siswa atau calon siswa yang minat belajar pada pelatih tersebut semakin banyak tanpa harus dibuat-buat pelatihan renang menjadi lebih lama.

Dengan pokok masalah yang dialami beberapa orang atau calon siswa renang maka pendekatan secara mendalam harus dilakukan, pendekatan pelatihan dalam penelitian ini muali dari pendekatan: (a) Psikologi, (b) latihan pernafasan, (c) urutan gerakan dengan bantuan pelatihan, dengan demikian diharapkan para siswa akan tidak mudah putus asa, cemas dan semakin giat belajar renang dengan baik dan dengan rasa yang senang. Dan penjabaran pendekatan tiga aitem tersebut ialah sebagai berikut: pendekatan psikologi seperti kecemasan dalam Adisasmito (2008) Faktor-faktor kecemasaan atau sumber-sumber kecemasan sebagai berikut:(a). Keluhan Somatis, Takut gagal, Perasaan tidak komplet (lengkap), Kehilangan Rasa Bersalah, Cita-cita yang tinggi, Diperhatikan orang Lain, Kegelisahan yang berlebihan, Kegagalan dalam pertandingan yang lalu, Cedera, Usia, Jenis Kelamin. Menurut Gunarsa dalam Apta, (2015) kecemasan merupakan suatu hal yang mutlak terjadi pada diri atlet/siswa renang sebelum melakukan pertandingan ataupun proses pembelajran renang, maka muncul berbagai pertanyaan mengenai bagaimana cara mengurangi tingkat kecemasan dan ketegangan tersebut, teknik atau pendekatan dapat dilakukan dengan cara sebagai berikut: (1) Strategi Relaksasi: Keadaan relaks adalah keadaan saat seorang atlet/siswa berada dalam kondisi emosi tenang, yaitu tidak bergelora atau tegang dan (2) Strategi kognitif: Strategi kognitif oleh pendekatan kognitif yang menekankan bahwa pikiran atau proses berpikir merupakan sumber kekuatan yang ada dalam diri seseorang. jadi kesalahan, kegagalan ataupun kekecewaan tidak disebabkan oleh objek dari luar, namun pada hakekatnya bersumber pada inti pikiran atau proses berpikir seseorang. Contoh: "Saya memusatkan perhatian terhadap komitmen saya untuk berlatih sesuai dengan apa yang diintruksikan pelatih".

Dengan pendekatan strategi kognitif dan relaks yang diberikan ke pada siswa oleh pelatih, diharapkan dapat mengurangi kecemasan yang timbul saat pembelajaran berlangsung.

Motivasi adalah energi psikologi yang bersifat abstrak. Wujudnya hanya dapat diamati dalam bentuk manifestasi tingkah laku yang ditampilkanya. Motivasi sebagai proses psikologis adalah refleksi kekuatan interaksi antara kognisi, pengalaman dan kebutuhan, dalam pendidikan jasmani dan olahraga, alderman menyebutkan bahwa tidak ada prestasi tanpa motivasi. Prestasi adalah 
amalgamasi latihan/keterampilan dengan motivasi (Husdarta, 2010). Secara sederhana, motivasi dapat didefinisikan sebagai penggerak atau pendorong seseorang untuk melakukan sesuatu. Motivasi memiliki arah dan insensitas. Arah merujuk apakah seseorang mencari, mendekati atau tertarik pada situasi tertentu. Sedangkan insensitas merujuk pada kesungguhan usaha yang dilakukan seseorang dalam situasi tertentu (Ali Maksum, 2011).

Menurut Irianto dalam Apta (2015) motivasi adalah sesuatu yang menggerakkan atau mendorong seseorang atau kelompok untuk melakukan atau tidak melakukan sesuatu. Diperkuat oleh sabron yang menyatakan bahwa motivasi adalah dorongan di dalam yang berupa harapan dan keinginan yang bersifat menggiatkan dan mengerakkan individu. Oleh sebab itu, diperlukan beberapa pendekatan teori motivasi yang diduga memiliki implikasi dalam proses pembelajaran pendidika jasmani atau Pelatihan olahraga, berikut teori-teori dalam Apta (2015) yaitu : (1) Teori hedonisme, yakni manusia akan memilih aktivitas yang menyebabkan perasaan gembira dan senang, Teori naluri, menghubungkan prilaku/semua aktivitas dengan berbagai naluri, (2) seperti naluri untuk mempertahankan diri, (3) Teori kebudayaan, menghubungkan tingkah laku betrdasarkan pola kebudayaan setempat, (4) Teori berprestasi, yang mendorong individu untuk berlomba dengan ukuran keunggulan, dan (5) Teori kebutuhan, yang menyatakan bahwa tingkah laku, pada hakikatnya bertujuan untuk memenuhi kebuutuhan

Dengan pendapat para ahli di atas maka seorang pelatih atau guru pengajar renang sangat penting dalam pemberian motivasi ke siswa renang dengan salah satunya yaitu dengan pendekatan motivasi verbal, dengan motivasi liwat ucapan dalam pembelajaran akan membuat atlet/siswa akan semakin termotivasi dalam pembelajaran. Teori maslow dan teori yang dikembangkan oleh Mylsidayu (2015) harus dikerjakan, dengan begitu kebutuhan yang aman, keamanan, perlindungan maka siswa akan merasa aman, menyenangkan dan bebas dari rasa takut dan akhirnya rasa cemas pun hilang dan pembelajaran renang dapat lancar dan terus menerus sesuai dengan waktu yang telah ditentukan.

Komunukasi dalam olahraga Istilah komunikasi dari kata latin comunicare atau communis yang berarti sama atau menjadi milik bersama. Apabila kita berkomunikasi dengan orang lain, berarti kita berusaha agar apa yang di sampaikan kepada orang lain tersebut menjadi miliknya. Menurut Suprapto komunikasi adalah suatu proses penyampaian pesanberupa lambang, suara, gambar dan sebagainya dari suatu sumber kepada sasaran (audiance) dengan menggunakan saluran tertentu. Sejalan dengan pendapat diatas, West turner komunikasi adalah proses sosial dimana individuindividu menggunakan simbol-simbol untuk menciptakan dan menginterpretasikan makna dalam likunganya (Mylsidayu,A, 2015). Jadi komunikasi menurut pendapat para ahli diatas dapat disimpulkan bahwa komunikasi adalah penyampaian pesan dari penyampai pesan ke penerima pesan melalui audio visual.

Tujuan komunikasi menjelaskan bahwa proses komunikasi secara spesifik mempelajari atau mengajarkan sesuatu, memengaruhi prilaku-seseorang, mengungkapkan perasaan, menjelaskan prilaku sendiri atau prilaku orang lain, berhubungan dengan orang lain menyelesaikan sebuah masalah dan menyampaikan sebuah tujuan.

Dengan demikian penelitian ini memberikan salah satu metode atau alternatif melatih renang dengan tujuan membuat para pelatih renang lebih mudah dalam melatih renang gaya dada.

\section{METODE \\ Model pengembangan}

Metode yang digunakan ialah pengembangan bahan ajar dalam bentuk buku pelatihan renang, dan dalam alur penelitian ini mereferensi dari Punaji, (2015). Adapun tahapan tahapan sebagai berikut: Tahap I: Pembuatan bahan ajar renang berupa buku saku pelatih dan buku pelatihan renang gaya dada, Tahap II: Membuat angket validasi ahli materi renang dan desain buku pembelajaran renang dan Membuat alat ukur berupa angket respon pelatih dan siswa renang yang di peruntukkan di validasi oleh ahli renang dan ahli psikologi olahraga, dan Tahap III: Pelaksanaan uji coba produk di lapangan atau di kolam renang Body art Surabaya.

\section{Instrumen Pengumpulan data}

Dalam penelitian metode pengumpulan data menggunakan angket yang diisi dan dijawab sendiri oleh responden yang diteliti. Dalam penelitian pengumpulan data dilakukan dengan menggunakan skala likert yang bervariasi dengan pernyataan-pernyataan melalui alternatif jawaban 
sebagai berikut: Sangat setuju (SS) Skor 4, Setuju (S) Skor 3, Tidak Setuju (TS) Skor 2, Sangat Tidak Setuju (STS) Skor 1.

Kisi-kisi atau Blue print angket dengan indikator untuk pelatih dan siswa renang yang diteliti sebagai beriku:

Tabel. 1 Blue Print Angket Pelatih dan Siswa Renang (Azwar, 2017)

\begin{tabular}{|c|c|c|c|}
\hline No & Responden & Indikator & Item peryataan \\
\hline \multirow{3}{*}{1} & \multirow{3}{*}{ Pelatih renang } & Kemenarikan metode pelatihan & $1,2,3,4,5,6,7$ \\
\hline & & Relevansi bahan untuk melatih & $12,13,14,17,20$ \\
\hline & & Manfaat bahan ajar yang dilatihkan & $8,9,10,11,15,16,18,19$ \\
\hline \multirow{3}{*}{2} & \multirow{3}{*}{ Siswa renang } & Kemenarikan bahan sajian yang dipelajari & $1,2,3,4,5,12,13,14$ \\
\hline & & Kemudahan dalam pembelajaran & $6,7,8,9,15,16$ \\
\hline & & Kenyamanan dalam pembelajaran & $10,11,17,18$ \\
\hline
\end{tabular}

\section{Uji Coba Produk}

Dalam pelaksanaan uji coba produk ini, ada beberapa hal yang di uraikan, yaitu mulai dari: Tempat di Kolam Renang Body Art, J1 Raya Mastrib No. 322-324 Sby dan waktu penelitian Tgl 5 juli 2018 - 10 Sept 2018.

Untuk mengetahui tingkat kemenarikan dan kemanfaatan produk pedoman pembelajaran renang gaya dada dan hal lainya, maka dilakukan serangkaian validasi terus kemudian diuji coba terhadap produk tersebut dan diadakan revisi. Seperti beberapa tahapan antara lain sebagai berikut :

Tinjauan ahli materi renang dan validasi, bertujuan untuk mendapatkan data berupa penilaian, pendapat dan saran terhadap kelayakan isi materi dan sajian materi buku produk pembelajaran renang gaya dada yang sudah dikembangkan.

Tinjauan ahli desain pembelajaran dan validasi, bertujuan untuk mendapatkan penilaian dan komentar serta saran terhadap desain, tata bahasa, dan kegrafisan produk pembelajaran renang gaya dada yang dikembangakan.

Uji coba perorangan, teman sejawat dan kelompok, penilaian uji coba ini mempunyai dua maksud pertama bagi guru renang atau pelatih renang yaitu kemenarikan metode pelatihan, relevansi bahan untuk melatih dan manfaat bahan ajar yang dilatihkan, kedua bagi siswa renang yaitu kemenarikan bahan sajian yang dipelajari, kemudahan dalam pembelajaran, dan kenyamanan dalam pembelajaran.

\section{Alur penelitian}

Uji Pakar

Dalam penelitian ini pengujian produk akan melalui beberapa tahapan yaitu:

Dari produk yang di buat terlebih dahulu ialah pedoman pelatihan renang gaya dada, pedoman di validasi isi dan konten oleh dua (2) ahli yaitu: (1) Ahli desain pembelajar yaitu Dosen mata kuliah desain pembelajaran Pendidikan Jasmani (PENJAS) Pascasarjana Unipa Surabaya, (2) Ahli Renang yaitu Dosen mata kuliah renang Unipa Surabaya.

Teman sejawat (Uji Pelatihan tahap 1)

(1) Buku pedoman Yogamethods yang sudah di validasi desain dan isi materi maka diuji coba oleh teman sejawat, Yogamethods ini diuji oleh 1 (satu) orang beserta siswa renang dan pembelajaran di lakukan di kolam renang Body Art, (2) Setelah diuji coba oleh teman sejawat beserta 1 (satu) siswa maka teman sejawat dan siswa tersebut di beri angket respon tentang Yogamethods. Dan akan direvisi bila ada catatan atau kekurangan dari masukan teman sejawat dan siswa renang.

Uji kelompok kecil (Uji Pelatihan tahap 2)

Setelah melalui uji teman sejawat maka Yogamethods diuji coba kelompok kecil yaitu 2 pelatih beserta siswanya. Dan setelah melakukan uji coba maka 2 (dua) Pelatih beserta siswanya diberi angket respon dan kemudian akan direvisi lagi bila ada catatan dan masukan dari pelatih kelompok kecil.

Uji kelompok besar ( Uji tahap 3)

Setelah uji coba kelompok kecil kemudian Yogamethods kelompok yang lebih besar seabanyak 10 pelatih renang berserta siswanya yang coba dilaksanakan maka para pelatih dan siswa juga diberi 
angket respon dari Yogamethods dan diadakan revisi lagi kalau ada catatan atau masukan dari pelatih kelompok besar beserta siswanya.

\section{Teknik Pengumpulan Data}

Data yang dikumpulkan dalam penelitian ini berupa data dari pelatih renang dan siswa renang, pengumpulan data menggunakan angket yang dikembangkan peneliti, kemudian diisi oleh para peatih beserta siswanya dengan menandai $(\sqrt{ })$ pada Option yang telah disediakan, selanjutnya dianalisis dengan menggunakan statistik deskriptif yang penyajianya dalam bentuk persentase dan rumus yang digunakan sebagai berikut:

Keterangan :

$$
\text { Persentase }=\frac{\sum \text { jawaban } \times \text { bobot tiap pilihan }}{\mathrm{N} \times \text { bobot terting }} \times 100
$$

$\sum=$ Jumlah

$\mathrm{N}=$ Jumlah seluruh item

Untuk dapat memberikan makna angka dan pengambilan keputusan pada tingkat kelayakan produk digunakan ketetapan sebagai berikut:

Tabel. 2 Konversi Tingkat Pencapaian dengan skala 4 (Arikunto, 2017)

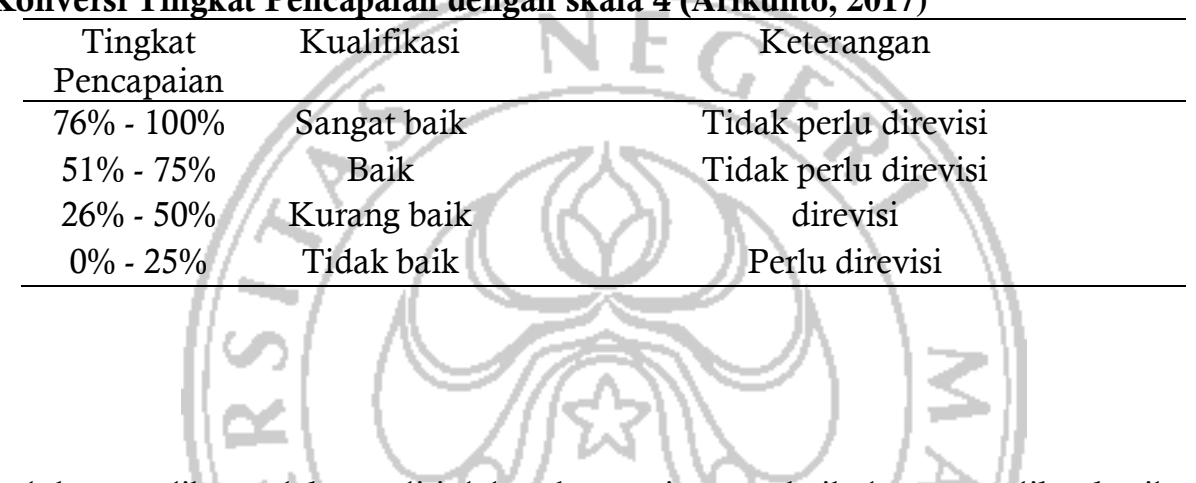

Produk yang dibuat oleh peneliti dalam kategori sangat baik dengan melihat hasil validasi dari ke dua ahli desain dan ahli materi renang yaitu Hasil validasi ahli desain sebesar $96 \%$ dan hasil dari validasi ahli materi renang sebesar $97.5 \%$. Karena rata-rata diatas $79 \%$. Maka bahan ajar sangat baik dan layak di implementasikan.

Pada Pada ujincoba lapangan pada siswa renang di kolam renang Body art mulai dari hasil analisis angket dari teman sejawat dengan hasil angket pelatih teman sejawat yaitu $87,5 \%$ dan siswa dari teman sejawat sebesar 80,55 maka produk layak diuji coba ke kelompok, hasil dari pelatih kelompok kecil yaitu $87,5 \%$ dan siswa dari kelompok kecil yaitu $86,6 \%$ maka produk layak di uji cobakan ke kelompok besar, hasil dari pelatih kelompok besar yaitu 90,1\% dan siswa kelompok besar yaitu $87,6 \%$ maka uji coba produk dinyatakan selesai dan layak di gunakan. 


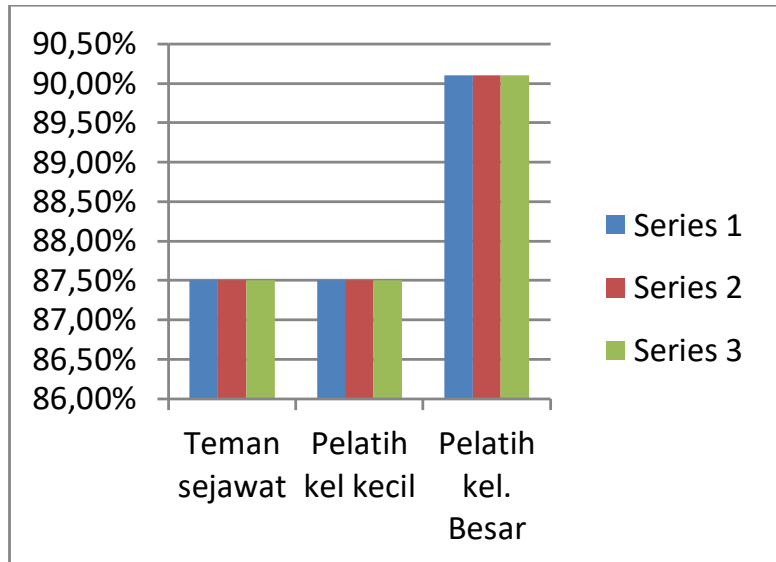

\section{Gambar 1. Grafik hasil uji coba lapangan Kelompok pelatih}

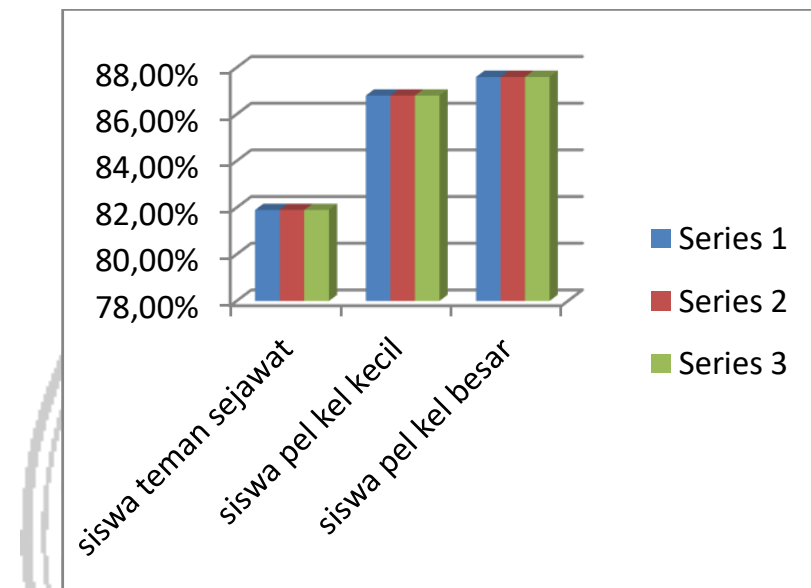

\section{PEMBAHASAN}

\section{Gambar 2. Grafik hasil uji coba lapangan Kelompok siswa}

Hasil penelitian pengembangan bahan ajar renang gaya dada untuk mempermudah melatih renang gaya dada ini telah selesai dengan hasil kategori sangat baik. Dalam penelitian ini unsur psikologi sangat dibutuh kan terutama motivasi seorang pelatih kepada siswanya atau perlakuan pelatih kepada siswa sangat membantu keberhasilan seorang siswa renang, olahraga renang sangat membantu dalam hal kesehatan dan kebugaran siswa, maka dari itu penelitian ini bermanfaat bagi kesehatan maka dari itu penelitian ini bermanfaat bagi kesehatan bagi manusia pada umunya dan guru pengajar renang gaya dada. ini dibuktikan dengan hasil dari teman sejawat kemudian kelompok kecil dan kelompok besar, dari tiga tahapan uji lapangan tersebut hasilnya dalam kategori sangat baik dan tidak perlu direvisi.

Hasil penelitian pengembangan ini mendukung hasil penelitian-penelitian sebelumnya. Hasil penelitian Zachary dkk (2019) menunjukkan hubungan yang signifikan juga ditemukan antara citra tubuh positif dan variabel terkait olahraga. Hasil ini berkontribusi temuan baru pada literatur citra tubuh dan potensi implikasi bagi pelatih untuk mendorong budaya yang kurang fokus pada penampilan tubuh dan lebih pada mengedepankan citra tubuh yang positif.

Hal yang sama ditunjukkan oleh hasil penelitian Lourdes Merono. dkk (2016) bahwa program intervensi berbasis pendidikan olahraga memiliki dampak positif pada peningkatan keterampilan berenang dan iklim motivasi yang lebih optimal.

Hasil penenlitian Austin R. Anderson dkk (2018) menunjukkan partisipasi dalam klub olahraga rekreasi di kampus adalah kegiatan mahasiswa yang populer di seluruh negeri. Organisasi berbasis olahraga ini memberikan sejumlah manfaat dalam dimensi kesehatan dan kesejahteraan yang diakui. 
Memahami motif peserta untuk terlibat dalam jenis kegiatan ini dapat memberikan wawasan dalam desain dan pengiriman dan meningkatkan kesehatan peserta.

Sedangkan hasil penelitian Smart dkk. (2018) menunjukkan kecemasan keadaan kompetitif adalah respon umum terhadap situasi olahraga kompetitif yang penuh tekanan yang dapat mempengaruhi kinerja atltetik. Efek kecemasan negara pada kinerja renang perlu penyelidikan lebih lanjut. Tujuan dari penelitian ini adalah untuk menentukan komponen kecemasan negara yang paling memprediksi kinerja renang.

Hasil penelitian Brian V. Wright \& Joel M. Stager (2018) menunjukkan ketaatan terhadap itensitas latihan yang ditentukan (kecepatan berenang) telah disampaikan sebagai parameter utama mengenai peningkatan kinerja musiman. Bukti juga menunjukkan bahwa perenang mengalami kesulitan mematuhi pelatihan yang ditentukan oleh pelatih. Bagaimana kepatuhan ini dipengaruhi oleh kehadiran dan pengawasan seorang pelatih

Hasil jurnal internasional di atas olahraga prestasi ataupun olahraga yang bersifat rekreasi mempunyai berbagai mafaat kesehatan dan kebugaran untuk manusia. dalam renang rekreasi ataupun prestasi pelaksanaan disetiap kegiatan olahraga tersebut sangat dibutuhkan motivasi, supaya kecemasan yang timbul dapat dikelola dengan baik dan tidak berpengaruh terhadap penampilan siswa, maka pada saat pelatihan renang sangat dibutuhkan kepatuhan siswa dalam alur pembelajaran atau pelatihan, dengan begitu pelaksanaan pelatihan akan menunjang keberhasilan seorang siswa renang.

\section{KESIMPULAN}

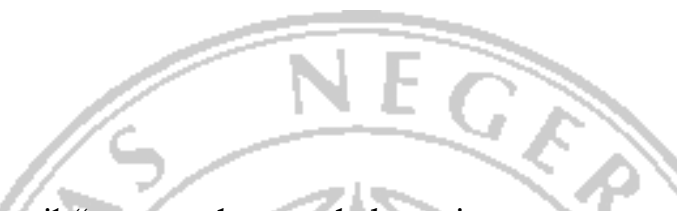

Berdasarkan pada hasil "pengembangan bahan ajar renang gaya dada untuk mempermudah melatih renang gaya dada" maka diperoleh simpulan sebagai berikut: Yogamethods sebagai alternative model pembelajaran renang gaya dada dengan praktis, Yogamethods mengedepankan pendekatan psikologis dan pendampingan secara intensif sehingga lebih efektif dalam proses pelatihan renang gaya dada. Dari hasil temuan tentang yogamethods, maka direkomendasikan bahwa dalam proses pembelajaran renang gaya dada diwajibkan untuk menggunakan model pembelajaran yogamethods khususnya untuk pelatihan renang dengan private.

\section{DAFTAR PUSTAKA}

Adisasmito, Lilik Sudarwati, 2008, Mental juara modal atlet berprestasi, Jakarta, PT Rajagrafindo Persada.

Ali, M. 2012. "Pengembangan Pendekatan Kontekstual Terhadap Hasil Belajar Renang Gaya Dada." Jurnal Penelitian Universitas Jambi. Volume 14, nomor 2. Universitas Jambi, Jambi.

Arikunto, Suharsimi. 2016, Dasar-dasar Evaluasi Pendidikan, Bumi Aksara, Jakarta.

Austin dan William. 2018. "Social motivation and health in college club swimming" Journal of American College Health. Volume 66, nomor 8.

Azwar, Saifuddin. 2017, Penyusunan Skala Psikologi, Pustaka Pelajar. Yogyakarta.

Dennison, Sriwahyuni, E., dan Wardhani, Vera. 2003. "Pengaruh Gaya Berenang (Gaya Bebas dan Gaya Dada) terhadap Perubahan Volume Oksigen Maksimum." Majalah Kedok Unibraw. XIX (2). Universitas Brawijaya, Malang.

Gunarsa, Singgih D, 2008, Psikologi Olahraga Prestasi. PT BPK Gunung Mulia, Jakarta.

Husdarta, 2011, Psikologi Olahraga. Alfa Beta, Bandung.

Lourdes, Merono. dkk, 2016 "Effect of Sport Education on the technical learning and motivational climate of junior high performance swimmers" Rev. int. cienc. Deporte XII, Nomor 44

Maksum, Ali. 2011, Psikologi Olahraga Teori dan Aplikasi. Unesa University Press, Surabaya.

Mylsidayu, A, 2015, Psikologi olahraga. PT Bumi Aksara, Jakarta. 
Ngafifi, Muhamad. 2014. "Kemajuan Teknologi dan Pola Hidup Manusia Dalam Perspektif". Jurnal Pembangunan Pendidikan: Fondasi dan Aplikasi. Volume 2, nomor 1.

Prasetyo, E., dan Yunus, M. 2017. Hubungan antara Frekuensi Gerakan Kaki dengan Prestasi Renang Gaya Crawl 50 Meter. Indonesia Performance. Volume 1 nomor $2 .$.

Punaji, 2015, Metode Penelitian Pendidikan \& Pengembangan, Malang: PT Kharisma Putra Utama.

Smart Z Mabweazara dkk 2018. "Predicting Swiming Performance using State Anxiety", South African Journal of Psychology. Volume 47, nomor 1.

Subagiyo dan Sismadiyanto .2001. "Peningkatan Hasil Belajar Renang Gaya Multi-Stroke Method \& Flipper 'Float Method" Sport Science: Jurnal Ilmu Keolahragaan, 2 (1), 41-54.

Soulliard, Z. A, dkk, 2019. Body image Novanthealth, 1, .1-5

Soulliard, Z. A, dkk, 2019. Body image Novanthealth, 1, .1-5

Sumaryoto dan Soni, 2017, Pendidikan Jasmani Olahraga dan Kesehatan SMA kelas IX, Kemendikbud RI, Jakarta.

Suryabrata, S, 2005, Pengembangan alat ukur psikologi, CV Andi Offset, Yogyakarta.

Susanto, Ermawan. (2010). "Manfaat Olah Raga Renang Bagi Lanjut Usia", Medikora, Volume XI, nomor 1. Universitas Negeri Yogyakarta, Yogyakarta.

Wright, B. V. and Stager, J. M. 2018. "Swimmers" Compliance to Training as a Function of Observation: A Pilot Study" Research Quarterly for Exercise and Sport. Volume 89, nomer 4.

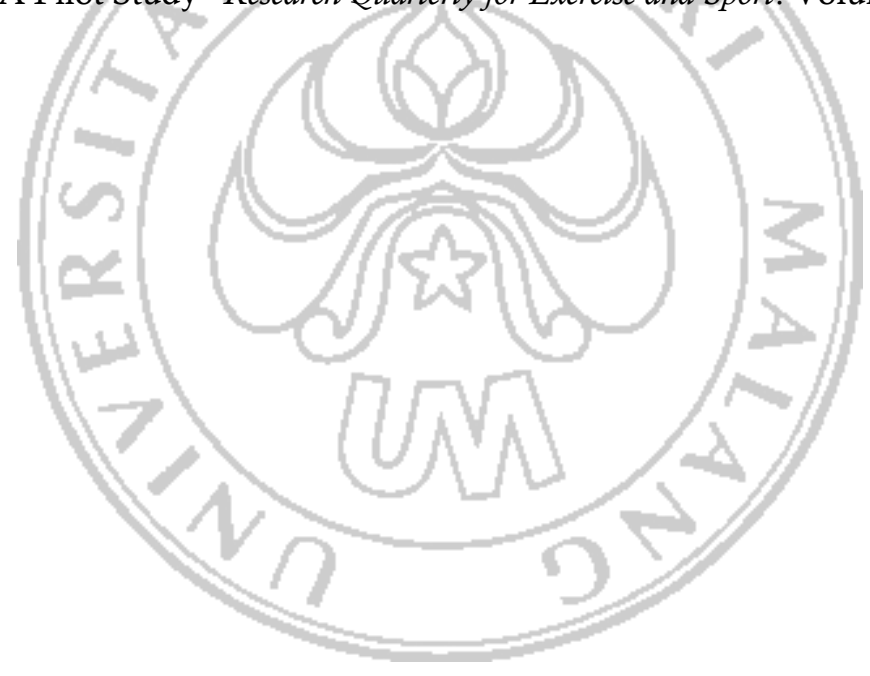

